\title{
Clinical spectrum of Pediatric HIV across A.R.T. centers in Chhattisgarh
}

\author{
Phuljhele $S^{1}$, Dewangan $S^{2}$, Sanadhya $S^{3}$ \\ ${ }^{1}$ Dr. Sharja Phuljhele, Professor, ${ }^{2}$ Dr. Shashikant Dewangan, Assistant Professor, ${ }^{3}$ Dr. Shrikant Sanadhya, \\ Resident, all authors are affiliated with Department of Paediatrics, Pt J.N.M. Medical College, Raipur, CG, India
}

Address for Correspondence: Dr. Shashikant Dewangan, Email: drshashikantdewangan@gmail.com

\begin{abstract}
Introduction: Pediatric HIV is a major world health problem, which is progressing at an alarming rate. Few studies have been done about variable clinical manifestation of pediatric HIV infection in children. This study intends to know the clinical profile of HIV infection in children of Chhattisgarh, evaluate the seroconversion rates of babies born to HIV seropositive women, possible maternal, obstetrical, and feeding factors influencing them, patient's adherence to ART and opportunistic infections in affected children. Methods: All pediatric HIV cases from $1 \frac{1 / 2}{2}$ year to 14 year registered in A.R.T. centres of Chhattisgarh. Data were analysed using SPSS system version 21. Result: A total of 414 children were evaluated from different A.R.T. centres in Chhattisgarh for final analysis. Male to female ratio is 1.38:1. Most common mode of transmission is from mother to child. Tuberculosis, Recurrent and Persistent Diarrhoea, Recurrent Pneumonia and Oral Candidiasis are common infection in most of the children. Conclusion: Average age of diagnosis of pediatric HIV is around $7.5 \pm$ 2.1years. Majority of children are diagnosed in stage 3. Adherence therapy to A.R.T. is good. Vertical transmission is most common mode of transmission.
\end{abstract}

Key words: Adherence rate, Clinical Spectrum, HIV, Opportunistic Infection, Transmission

\section{Introduction}

Human immunodeficiency virus (HIV) is a lentivirus (a member of the retrovirus family) that causes acquired immunodeficiency syndrome (AIDS), a condition in humans in which the immune system begins to fail, leading to lifethreatening opportunistic infections $[1,2]$. Infection with HIV occurs by the transfer of blood, semen, vaginal fluid, pre-ejaculate or breast milk $[3,4,5,6]$.

Pediatric HIV is becoming a major public health problem in India with rising trend of HIV infection in pregnant women [7, 8,]. Children experience more rapid disease progression than adults, with up to half of the untreated children dying within the first 2 year of life.

This rapid progression is correlated with a higher viral burden and faster depletion of infected CD4 lymphocytes in infant and children than in adult.

Manuscript received: $8^{\text {th }}$ August 2017

Reviewed: $18^{\text {th }}$ August 2017

Author Corrected: $25^{\text {th }}$ August 2017

Accepted for Publication: $30^{\text {th }}$ August 2017
Accurate diagnostic test and early use of potent drugs to inhibit HIV replication have dramatically increase the ability to prevent and control of this disease $[9,10]$.

According to the Joint United Nations Programme on HIV and AIDS (UNAIDS) 36.7 million people and 1.8 million children under 15 years of age were living with HIV worldwide in 2015 [11]. 2.1 million people and 150,000 children under 15 years of age were newly infected with HIV [11]. 1.1 million people and 110,000 children under 15 years of age were AIDS related deaths in 2015 worldwide [11].

The total numbers of people living with HIV in India were estimated at 21.17 lakhs (17.11 lakhs26.49 lakhs) in 2015 compared with 22.26 lakhs (18.00 lakhs-27.85 lakhs) in 2007[12]. Children (< 15 years) account for $6.54 \%$, while two fifth (40.5\%) of total HIV infections are among female, 
Children ( $<15$ years) accounted for 12\% (10.4 thousand) of total new infections [12].

Vertical transmission (mother to child) is the main route by which childhood HIV infection is acquired [13, 14]. HIV can pass from an HIV positive mother to her child during pregnancy through placenta, during childbirth through mother's cervical secretion or blood and afterbirth through breastfeeding $[3,15]$.

Other modes of transmission are through infected syringes and through infected blood transfusion $[16,17,18]$. Clinical spectrum of HIV ranges from asymptomatic infection to florid AIDS [19, 20].

There is paucity of clinical data regarding Pediatric HIV in Chhattisgarh hence this study was undertaken to know the clinical profile of HIV infection in children of Chhattisgarh, evaluate the seroconversion rate of babies born to HIV seropositive women, maternal, obstetrical, feeding factors influencing them, patient's adherence to ART and opportunistic infections occurring in HIV affected children.

\section{Material and Methods}

Study design: Retrospective and prospective crosssectional observational study

Setting: Hospital based study at ART centres of Chhattisgarh.

Inclusion criteria: $1 \frac{1}{2}$ year to 14 years children registered at ART centres.

Exclusion criteria: Below 11/2 year and above 14 years.

Participants: HIV positive children from age $1 \frac{1}{2}$ to 14 years registered in ART centres of Chhattisgarh

Variables: Age, Sex, Mode of transmission, Compliance to ART, Opportunistic infection

Data Source: Record review of data registered at ART centres.

Bias: Reporting bias, observation bias

Study size: 414 children registered at ART centres

Statistical methods: Measurement of central tendency and dispersion

\section{Result}

A total of 414 children from age of 18 months to 14 years were evaluated from different ART centre in Chhattisgarh.

Table-1: Sex wise distribution of HIV positive children registered at ART centres

\begin{tabular}{|c|c|c|}
\hline Sex & HIV positive children & Percentage \\
\hline Male & 240 & 58 \\
\hline Female & 174 & 42 \\
\hline Total & $\mathbf{4 1 4}$ & $\mathbf{1 0 0}$ \\
\hline
\end{tabular}

There is higher prevelence of HIV in boys (58\%) as compared to girls (42\%)

Table-2: Different mode of HIV transmission among children registered at ART centres

\begin{tabular}{|c|c|c|}
\hline Risk factor & Frequency & Percent \\
\hline Mother To Child & 300 & 72.5 \\
\hline Blood Transfusion & 61 & 14.7 \\
\hline Unknown & 53 & 12.8 \\
\hline Total & $\mathbf{4 1 4}$ & $\mathbf{1 0 0 . 0}$ \\
\hline
\end{tabular}

In our study most common mode of Transmission is Mother to Child $72.5 \%$, followed by Blood Transfusion $14.7 \%$. In about $13 \%$ cases cause could not be identified. 
Table-3: Mother's HIV status of children enrolled in study.

\begin{tabular}{|c|c|c|}
\hline HIV Status Mother & Frequency & Percent \\
\hline Positive & 296 & 71.5 \\
\hline Negative & 87 & 21 \\
\hline Unknown & 31 & 7.5 \\
\hline Total & $\mathbf{4 1 4}$ & $\mathbf{1 0 0}$ \\
\hline
\end{tabular}

In our study $71.5 \%$ Mothers were HIV positive, $21 \%$ Mothers were HIV Negative and in 7.5\% HIV status were Unknown.

Table- 4: Adherence to ART of HIV positive children registered at ART centres

\begin{tabular}{|c|c|c|}
\hline Adherence & Frequency & Percent \\
\hline $96 \%$ to $100 \%$ & 280 & 67.6 \\
\hline $91 \%$ to $95 \%$ & 52 & 2.2 \\
\hline Less than $90 \%$ & 9 & $\mathbf{1 0 0 . 0}$ \\
\hline Total & $\mathbf{4 1 4}$ & 12.6 \\
\hline
\end{tabular}

In our study $67.6 \%$ patient had $96-100 \%$ adherence to therapy followed by $12.6 \%$ children had $91-95 \%$ adherence to therapy.

Table- 5: CD4 count at different time interval during the course of ART

\begin{tabular}{|c|c|c|c|c|c|}
\hline $\begin{array}{c}\text { CD4 count } \\
\text { (per } \mathbf{~ m m}^{\mathbf{3}} \text { of } \\
\text { blood) }\end{array}$ & At 1 $\mathbf{1}^{\text {st }}$ visit & $\begin{array}{c}\text { At ART } \\
\text { Medical } \\
\text { Eligibility }\end{array}$ & $\begin{array}{c}\text { At 1 month } \\
\text { after start of } \\
\text { ART }\end{array}$ & $\begin{array}{c}\text { At } 6 \text { month } \\
\text { after start of } \\
\text { ART }\end{array}$ & $\begin{array}{c}\text { At 12 month } \\
\text { after start of } \\
\text { ART }\end{array}$ \\
\hline More than 500 & $55.8 \%$ & $33.4 \%$ & $37 \%$ & $46 \%$ & $47.8 \%$ \\
\hline $200-500$ & $31.4 \%$ & $37.7 \%$ & $33.5 \%$ & $22 \%$ & $18.6 \%$ \\
\hline $100-200$ & $8.9 \%$ & $9.9 \%$ & $12 \%$ & $3.9 \%$ & $1.9 \%$ \\
\hline Less than 100 & $3.8 \%$ & $4.3 \%$ & $2.9 \%$ & $0.96 \%$ & $0.48 \%$ \\
\hline
\end{tabular}

In our study there is gradual improvement in CD4 count with start of ART. In $14.4 \%$ cases CD4 count is increased to a level of more than $500 / \mathrm{mm}^{3}$.

Table- 6: Opportunistic Infection among HIV positive childrens

\begin{tabular}{|c|c|c|}
\hline Opportunistic infection & Frequency & Percentage \\
\hline Recurrent \& Persistent Diarrhea & 174 & $42.1 \%$ \\
\hline TB (Pulmonary \& Extra Pulmonary) & 120 & $29 \%$ \\
\hline Recurrent Pneumonia & 70 & $16.8 \%$ \\
\hline Oral Candidacies & 63 & $15.2 \%$ \\
\hline Sepsis & 36 & $8.6 \%$ \\
\hline Recurrent or Chronic Ear Infection & 18 & $4.3 \%$ \\
\hline Herpes Infection & 18 & $4.3 \%$ \\
\hline Meningitis & 15 & $3.62 \%$ \\
\hline Scabies & 14 & $3.4 \%$ \\
\hline Pneumocystis Pneumonia & 7 & $1.6 \%$ \\
\hline Recurrent Pyoderma & 4 & $0.9 \%$ \\
\hline
\end{tabular}

This table give us a view of all major opportunistic infection recorded in our study. Diarrhoea and Tuberculosis were two most common infections observed. 


\section{Discussion}

In our study, male to female ratio came out to be $1.38: 1$. $43 \%$ cases were between age group 18 months to 5 years, $34.3 \%$ cases between $6-10$ years, and $22.7 \%$ cases between $10-14$ years were observed. Similar findings were observed in a study conducted by Ramesh R. Pol in April 2004 to June 2005 at Karnataka, 49.3\% children were between 1.5 to 5 years and in Merchant RH, $74.73 \%$ patients were below the age of five years [21, 22]. In other Indian studies males slightly outnumbered females $[15,23,24]$. In other studies across the globe male were more than females $[25,26]$ but in one study from Nigeria male to female ratio was 1:1.14 [27]. In this study average age of diagnosis was around 7.5 year (90 months). In other Indian studies mean age of diagnosis were 50, 54 and 75 months [28, 29, 30].

The most common mode of HIV transmission was from mother to child in $72.5 \%$ cases, followed by blood transfusion in $14.7 \%$, and in $12.8 \%$ cases transmission is unknown. Similar findings were observed in other studies [22,29,30].

In our study $71.5 \%$ mothers were found to be HIV Positive, $21 \%$ were HIV Negative, status of $7.5 \%$ mother was unknown. In a study conducted from 2000 to 2001 at Mumbai, 78\% mothers were found to be HIV Positive [19]. In another study from Cameroon in 2011, the HIV status of more than half of the mothers was known and all of them were positive, whereas the HIV status of most of the fathers was not known [25].

In the present study $75.1 \%$ mothers were alive. In a study from South Africa on pediatric antiretroviral programme found that $61.8 \%$ mothers and $56.37 \%$ fathers were alive at the time of enrolment of children between age group of 4-17 years [31], while in an Indian study 94\% mother and 90\% fathers were alive during study [19].

Most of the patients (67.6\%) shows 96-100\% adherence to ART, followed by $12.6 \%$ which show $91-95 \%$ adherence, less than $90 \%$ adherence is $2.2 \%$. In a study done in South India at Bengaluru, Karnataka, $90.9 \%$ of the children were optimally adherent [32]. Most studies from low- and middleincome countries reported more than $75 \%$ adherence, whereas most studies from high-income countries report $<75 \%$ adherence [33]. In the present study $80.9 \%$ were on ART and $19.1 \%$ were on pre ART. In the study conducted by Rakesh Lodha et al in 2006 at Delhi, 57.73\% children were receiving antiretroviral drugs, $46.27 \%$ children did not opt for antiretroviral therapy [20]. Children receiving antiretroviral therapy showed improvement in nutritional parameters [20].

There is significant improvement in CD4 count following ART therapy. Before the start of ART $33.4 \%$ children had CD 4 count more than 500. At the end of 12 month of ART $47.8 \%$ children had CD4 count more than 500 . In the study conducted by Sunil Gomber in December 2008 to June 2009 at ART centers of Delhi, there was significant improvement in both clinical and immunological (CD4 count) staging at the 6 month after initiaiont on ART [34]. Baseline CD4 counts rather than clinical staging can be a primary determinant for initiation of antiretroviral treatment in HIV infected children (35). In other studies across the globe CD4 count increases following ART [35, 36, 37, 38].

In our study prevalence of opportunistic infection was $46.5 \%$. Tuberculosis was the most common opportunistic infection seen in $29 \%$ of children. The most common clinical manifestations in our study were Anemia 47.3\%, Recurrent and persist Diarrhea 42.1\%, Recurrent Respiratory tract Infection 36.4\% (Recurrent URTI 19.6\% and Recurrent LRTI 16.8\%), Malnutrition 37.1\%, Recurrent oral lesions 34.6\% (Recurrent Oral ulcer 19.4\%, Recurrent Oral Candidiasis 15.2\%), Tuberculosis 29\%, Lymphadenopathy $26.5 \%$, Dermatitis 21\% and Hepato-splenomegaly 13.4\%.

The common clinical findings in a study carried out at Cameroon were prolonged fever $44.6 \%$, malnutrition $37.6 \%$, lymphadenopathy $34.4 \%$, respiratory tract infections $34.4 \%$ and diarrhea $24.5 \%$ [31]. In India, the main clinical manifestations were oral candidiasis $43 \%$, pulmonary tuberculosis $35 \%$, recurrent respiratory infections $26 \%$, bacterial skin infection $21 \%$, papulo-pruritic dermatitis 19\%, hepatospleenomegaly and lymphadenopathy $14 \%$ each and chronic diarrhea 7\% [24]. Similar findings observed in others Indian studies [19, 20, 21, 22, 23]. 


\section{Conclusion}

In this study Vertical transmission is most common mode of transmission of perinatal HIV. Average age of diagnosis is around 7.5 years. This delayed diagnosis could be due to unawareness and lack of diagnostic facilities. In this study majority of children are diagnosed in stage 3 means they are having clinical signs and symptoms of AIDS. Tuberculosis is the most common infection with majority of children are presenting with pulmonary tuberculosis. Adherence therapy to ART is good. There is need of proper antenatal care and early identification and treatment of HIV positive mothers so vertical transmission can be reduced. There is also need of early diagnosis of HIV positive children so that they can be picked up in stage 1 or 2 and there proper treatment can be started.

What is already known- No information is available for clinical spectrum of Pediatric HIV in Chhattisgarh state.

What this study adds- There is late diagnosis of Pediatric HIV in Chhattisgarh though adherence to ART is good.

\section{Contributors}

- Shrikant Sanadhaya: Visited ART centres and collected DATA.

- Shashikant Dewangan: Analyzed data, Prepared manuscript and submitted article.

- Sharja Phuljhele: Supervised the research work.

\section{Funding: Nil, Conflict of interest: None} Permission of IRB: Yes

\section{References}

1. Weiss RA. How does HIV cause AIDS? Science. 1993 May 28;260(5112):1273-9.

2. Douek DC, Roederer M, Koup RA. Emerging concepts in the immunopathogenesis of AIDS. Annu Rev Med. 2009; 60:471-84. doi: 10.1146/ annurev.med.60.041807.123549

3. Dunn DT, Newell ML, Ades AE, Peckham CS. Risk of human immunodeficiency virus type 1 transmission through breastfeeding. Lancet. 1992 Sep 5;340(8819):585-8.
4. Leroy V, Newell ML, Dabis F, Peckham C, Van de Perre P, Bulterys M, Kind C, Simonds RJ, Wiktor S, Msellati P. International multicentre pooled analysis of late postnatal mother-to child transmission of HIV-1 infection. Lancet. 1998 Aug 22; 352(9128):597-600 . PMID: 974601

5. Pilcher CD, Shugars DC, Fiscus SA, Miller WC, Menezes P, Giner J, Dean B, Robertson K, Hart CE, Lennox JL, Eron JJ Jr, Hicks CB. HIV in body fluids during primary HIV infection: implications for pathogenesis, treatment and public health. AIDS. 2001 May 4;15(7):837-45.

6. Ammann AJ, Cowan MJ, Wara DW, Weintrub P, Dritz S, Goldman H, Perkins HA. Acquired immunodeficiency in an infant: possible transmission by means of blood products. Lancet. 1983 Apr 30;1 (8331): 956-8.

7. Gupta S, Gupta R, Singh S. Seroprevalence of $\mathrm{HIV}$ in pregnant women in North India: a tertiary care hospital based study. BMC Infect Dis. 2007 Nov 15;7:133. DOI: 10.1186/1471-2334-7-133

8. Lodha R, Singhal T, Jain Y, Kabra SK, Seth P, Seth V. Pediatric HIV infection in a tertiary care center in North India: early impressions. Indian Pediatr. 2000 Sep;37(9):982-6.

9. Hazra R, Siberry GK, Mofenson LM. Growing up with HIV: children, adolescents, and young adults with perinatally acquired HIV infection. Annu Rev Med. 2010;61:169-85. doi: 10.1146/ annurev. med.050108. 151127.

10. Song R, Jelagat J, Dzombo D, Mwalimu M, Mandaliya K, Shikely K, Essajee S. Efficacy of highly active antiretroviral therapy in HIV-1 infected children in Kenya.Pediatrics. 2007 Oct; 120 (4):e856-61. Epub 2007 Sep 10.

11. Global AIDS Update 2016 - unaids. Available from www. unaids.org/ sites/default/files/media_ asset/ global-AIDS-update-2016_en.pdf. Accessed on Ap. $28^{\text {th }}, 2016$

12. India HIV Estimations 2015-Naco.Available from www.naco.gov.in/sites/ default/files/ India \%20 HIV\%20 Estimations\%202015.pdf. Accessed on Ap. $28^{\text {th }}, 2016$. 
13. Peckham C, Gibb D. Mother-to-child transmission of the human immunodeficiency virus. N Engl J Med. 1995 Aug 3;333(5): 298302.

14. Minkoff H, Burns DN, Landesman S, Youchah J, Goedert JJ, Nugent RP, Muenz LR, Willoughby $\mathrm{AD}$. The relationship of the duration of ruptured membranes to vertical transmission of human immunodeficiency virus. Am J Obstet Gynecol. 1995 Aug;173(2):585-9.

15. Dhurat R, Manglani M, Sharma R, Shah NK. Clinical spectrum of HIV infection. Indian Pediatr. 2000 Aug; 37 (8):831-6.

16. Dodd RY. Current viral risks of blood and blood products. Ann Med. 2000 Oct;32(7): 469-74.

17. Kiwanuka N, Gray RH, Serwadda D, Li X, Sewankambo NK, KigoziG, Lutalo T, Nalugoda F, Wawer MJ. The incidence of HIV-1 associated with injections and transfusions in a prospective cohort, Rakai, Uganda. AIDS. 2004 Jan 23;18(2): $342-4$.

18. Gisselquist DP. Estimating HIV-1 transmission efficiency through unsafe medical injections. Int $\mathbf{J}$ STD AIDS. 2002 Mar;13(3): 152-9. DOI:10.1258/ 0956462021924820

19. Shah SR, Tullu MS, Kamat JR. Clinical profile of pediatric HIV infection from India. Arch Med Res. 2005 Jan-Feb; 36(1):24-31.

20. Lodha R, Upadhyay A, Kapoor V, Kabra SK. Clinical profile and natural history of children with HIV infection. Indian J Pediatr. 2006 Mar;73 (3): 201-4.

21. Pol RR, Shepur TA, Ratageri VH. Clinicolaboratory profile of pediatric HIV in Karnataka. Indian J Pediatr. 2007 Dec;74(12):1071-5.

22. Merchant RH, Oswal JS, Bhagwat RV, Karkare J. Clinical profile of HIV infection. Indian Pediatr. 2001 Mar; 38(3):239-46.

23. Daga SR, Verma B, Gosavi DV. HIV infection in children: Indian experience Indian Pediatr. 1999 Dec;36 (12):1250-3.
24. Madhivanan P, Mothi SN, Kumarasamy N, Yepthomi T, Venkatesan C, Lambert JS, Solomon S.Clinical manifestations of HIV infected children. Indian J Pediatr. 2003 Aug; 70 (8): 615-20.

25. Fru FS, Chiabi A, Nguefack S, Mah E, Takou V, Bogne JB, Lando M, Tchokoteu PF, Mbonda E. Baseline demographic, clinical and immunological profiles of HIV-infected children at the Yaounde Gynaeco-Obstetric and Pediatric hospital, Cameroon. Pan Afr Med J. 2014Feb3;17:87. PMCID: PMC4247732doi: 10.11604/pamj. 2014. 17.87.3264

26. Diack MA, Signaté SH, Diagne Guèye NR, Syllab A, Diouf A, Diagne I, et al. Epidemiological and clinical aspects of pediatric HIV infections in Albert-Royer Pediatric hospital (Dakar, Senegal). Arch Pediatr. 2005; 12(4): 404-9. DOI:10.1016 /j.arcped.2005.01.011

27. Fetuga MB, Ogunfowora OB, Oyegunle VN, Thanni LO. A ten-year review of paediatric HIV/AIDS among hospitalized children in a Nigerian teaching hospital. Nig J Paediatr. 2005; 32 (3) :29-32.

28. Shah I. Age related clinical manifestations of HIV infection in Indian children. J Trop Pediatr. 2005 Oct; 51 (5): 300-3. Epub 2005 Jun 24

29. Singh S, Jat KR, Minz RW, Arora S, Suri D, Sehgal S. Clinical profile of 516 children affected by HIV in a tertiary care centre in Northern India:14 years of experience. Trans R Soc Trop Med Hyg. Jun 2009;103(6):627-33. DOI:10.1016/j. trstmh.2009.01.009

30. Brown BJ, Oladokun RE, Odaibo GN, Olaleye DO, Osinusi K, Kanki P. Clinical and immunological profile of pediatric HIV infection in Ibadan, Nigeria. J Int Assoc Physicians AIDS Care (Chic). 2011Jan/Feb;10(1):49-53.DOI:10.1177/ 15451097 10385124

31. Sphiwe Madiba. "Patterns of HIV Diagnosis Disclosure to Infected Children and Family a Paediatric Antiretroviral Program in South Africa". World Journal of AIDS, 2012, 2, 212-221. DOI: 10. $4236 /$ wja.2012.23027 
32. Mehta K, Ekstrand ML, Heylen E, Sanjeeva GN, Shet A. Adherence to Antiretroviral Therapy Among Children Living with HIV in South India. AIDS Behav.2016May;20(5):1076-83.doi: 10.1007 /s 10461-015-1207-7.

33. Vreeman RC, Wiehe SE, Pearce EC, Nyandiko WM. A systematic review of pediatric adherence to antiretroviral therapy in low- and middle-income countries. Pediatr Infect Dis J. 2008 Aug;27(8): 686-91.doi:10.1097/INF.0b013e 31816dd325.

34. Gomber S, Kaushik JS, Chandra J, Anand R. Profile of HIV infected children from Delhi and their response to antiretroviral treatment. Indian Pediatr. 2011 Sep;48(9):703-7.

35. Lawn SD, Myer L, Bekker LG, Wood R. CD4 cell count recovery among HIV-infected patients with very advanced immuno-deficiency commencing antiretroviral treatment in subSaharan Africa. BMC Infect Dis. 2006 Mar 21;6: 59. doi: 10.1186/1471-2334-6-59
36. Rajesh R, Vidyasagar S, Varma DM, Naik A, Hegde BM, Guddattu V, Kamath A. A prospective study of highly active antiretroviral therapy in Indian human immunodeficiency virus positive patients. Int J Risk Saf Med. 2013 Jan 1;25(1):5365. doi: 10.3233/JRS-130580.

37. Kaufmann GR, Furrer H, Ledergerber B, Perrin L, Opravil M, Vernazza P, Cavassini M, Bernasconi E, Rickenbach M, Hirschel B, Battegay M: Swiss HIV Cohort Study. Characteristics, determinants, and clinical relevance of CD4 T cell recovery to $<500$ cells/microL in HIV type 1 infected individuals receiving potent antiretroviral therapy. Clin Infect Dis. 2005 Aug 1;41(3):361-72. Epub 2005 Jun 24.

38. García F, de Lazzari E, Plana M, Castro P, Mestre G, Nomdedeu M, Fumero E, Martínez E, Mallolas J, Blanco JL, Miró JM, Pumarola T, Gallart T, Gatell JM. Long-term CD4+ T-cell response to highly active antiretroviral therapy according to baseline CD4+ T-cell count. J Acquir Immune Defic Syndr. 2004 Jun 1;36 (2): 702-13.

\section{How to cite this article?}

Phuljhele S, Dewangan S, Sanadhya S.Clinical spectrum of Pediatric HIV across A.R.T. centers in Chhattisgarh. Int J Med Res Rev 2017;5(08):802-808.doi:10.17511/ijmrr. 2017.i08.05. 